COMPLEJQ ASISTENCIAL UNIVERSITARIO פSALAMANCA

\section{FLUCTUATING LEVELS OF CONSCIOUSNESS WITH VASCULAR ORIGIN: A CASE SERIES}

Authors: Domínguez Díez F.J.; Martínez Peralta S.; Álvarez Álvarez, M; Gómez Estévez l.; López Agudelo

O.A.; Sierra Gómez A.; Alonso Jiménez, A.; Alañá García M.; Martín Polo J.

Service of Neurology. Hospital Universitario de Salamanca - Spain

\section{Introduction}

\section{Objective}

\section{Material and methods}

We present a series of clinical cases with 4 patients with coma, fluctuating levels of consciousness and vertical ophthalmoplegia which revealed synchronous bilateral paramedian thalamic infarcts.
An adequate differential diagnosis is essential in patients with an acutely decreased level of consciousness

\begin{tabular}{|c|c|c|c|c|}
\hline & PATIENT 1 & PATIENT 2 & PATIENT 3 & PATIENT 4 \\
\hline SEX/AGE & Man. 80 years old. mRankin 0 & Man. 63 years old. mRankin 0 & Woman. 83 years old. mRankin 3 & Man. 62 years old. mRankin 0 \\
\hline CVRF & Arterial hypertension & $\begin{array}{l}\text { Arterial hypertension, DM Type } \\
\text { 2, dyslipidemia }\end{array}$ & Arterial hypertension & None \\
\hline $\begin{array}{l}\text { PREVIOUS } \\
\text { HISTORY }\end{array}$ & $\begin{array}{l}\text { Atrial fibrillation, ischemic } \\
\text { cardiopathy, biological aortic } \\
\text { valve, colon adenocarcinoma, } \\
\text { complete right facial paralysis }\end{array}$ & $\begin{array}{l}\text { Obesity, atrial fibrillation, } \\
\text { hyperuricemia, sleep apnea } \\
\text { syndrome }\end{array}$ & $\begin{array}{l}\text { Cognitive deterioration, ischemic } \\
\text { neuropathy of the left VI cranial } \\
\text { nerve in } 2009\end{array}$ & $\begin{array}{l}\text { Laryngeal carcinoma treated } \\
\text { with chemotherapy and } \\
\text { radiotherapy in } 2012\end{array}$ \\
\hline $\begin{array}{l}\text { MEDICAL } \\
\text { HISTORY }\end{array}$ & $\begin{array}{l}\text { Dizziness, diplopia, sudden loss } \\
\text { of level of consciousness }\end{array}$ & $\begin{array}{l}\text { Right-sided hemiparesis and } \\
\text { sudden loss of level of } \\
\text { consciousness }\end{array}$ & $\begin{array}{l}\text { Sudden loss of level of } \\
\text { consciousness }\end{array}$ & $\begin{array}{l}\text { Dizziness, progressive loss of } \\
\text { level of consciousness }\end{array}$ \\
\hline $\begin{array}{l}\text { PHISICAL } \\
\text { EXAM }\end{array}$ & $\begin{array}{l}\text { Fluctuating level of } \\
\text { consciousness, bilateral eyelid } \\
\text { ptosis, complete vertical } \\
\text { ophthalmoplegia }\end{array}$ & $\begin{array}{l}\text { Fluctuating level of } \\
\text { consciousness, complete paralysis } \\
\text { of the left III cranial nerve, } \\
\text { limitations for supraversion of } \\
\text { right eye, right supranuclear facial } \\
\text { paralysis, } 3 / 5 \text { paresis of upper } \\
\text { right limb }\end{array}$ & $\begin{array}{l}\text { Fluctuating level of } \\
\text { consciousness, pinpoint and } \\
\text { reactive pupils, complete vertical } \\
\text { ophthalmoplegia }\end{array}$ & $\begin{array}{l}\text { Fluctuating level of } \\
\text { consciousness, dysarthria, } \\
\text { bilateral eyelid ptosis, right } \\
\text { nonreactive mydriasis, vertical } \\
\text { conjugate gaze palsy, horizontal } \\
\text { conjugate gaze palsy to the left } \\
\text { with internuclear } \\
\text { ophthalmoplegia. Left } \\
\text { hemiparesia. }\end{array}$ \\
\hline $\begin{array}{l}\text { INICIAL CT } \\
\text { SCAN }\end{array}$ & Normal & Normal & Normal & Normal \\
\hline $\begin{array}{l}\text { CONTROL } \\
\text { MRI OR CT } \\
\text { SCAN }\end{array}$ & $\begin{array}{l}\text { Bilateral paramedian thalamic } \\
\text { infarct }\end{array}$ & $\begin{array}{l}\text { Bilateral paramedian thalamic } \\
\text { infarct }\end{array}$ & $\begin{array}{l}\text { Bilateral paramedian thalamic } \\
\text { infarct }\end{array}$ & $\begin{array}{l}\text { Multiple hypodense lesions on } \\
\text { right occipital lobe, both halves } \\
\text { of the thalamus, right } \\
\text { hemimesencephalon and left } \\
\text { cerebellum }\end{array}$ \\
\hline OTHER TESTS & Severe mitral insufficiency & Infratherapeutic INR values & Renal insufficiency. Anemia & No significant findings \\
\hline EVOLUTION & $\begin{array}{l}\text { Progressive improvement of } \\
\text { fluctuating level of } \\
\text { consciousness. Persistence of } \\
\text { ophthalmoplegia }\end{array}$ & $\begin{array}{l}\text { rtPA fibrinolysis. Initial admission } \\
\text { in ER with respiratory failure. } \\
\text { Conversion to apixaban. } \\
\text { Persistence of fluctuating level of } \\
\text { consciousness, oculomotor } \\
\text { alterations and behavioral } \\
\text { disorders }\end{array}$ & $\begin{array}{l}\text { Progressive improvement of } \\
\text { fluctuating level of consciousness. } \\
\text { Persistence of ophthalmoplegia }\end{array}$ & $\begin{array}{l}\text { Admission in ER for mechanical } \\
\text { ventilation. Severe hospital- } \\
\text { acquired pneumonia. Placement } \\
\text { of PEG. Persistence of } \\
\text { fluctuating level of } \\
\text { consciousness and oculomotor } \\
\text { alterations }\end{array}$ \\
\hline
\end{tabular}

\section{Results}

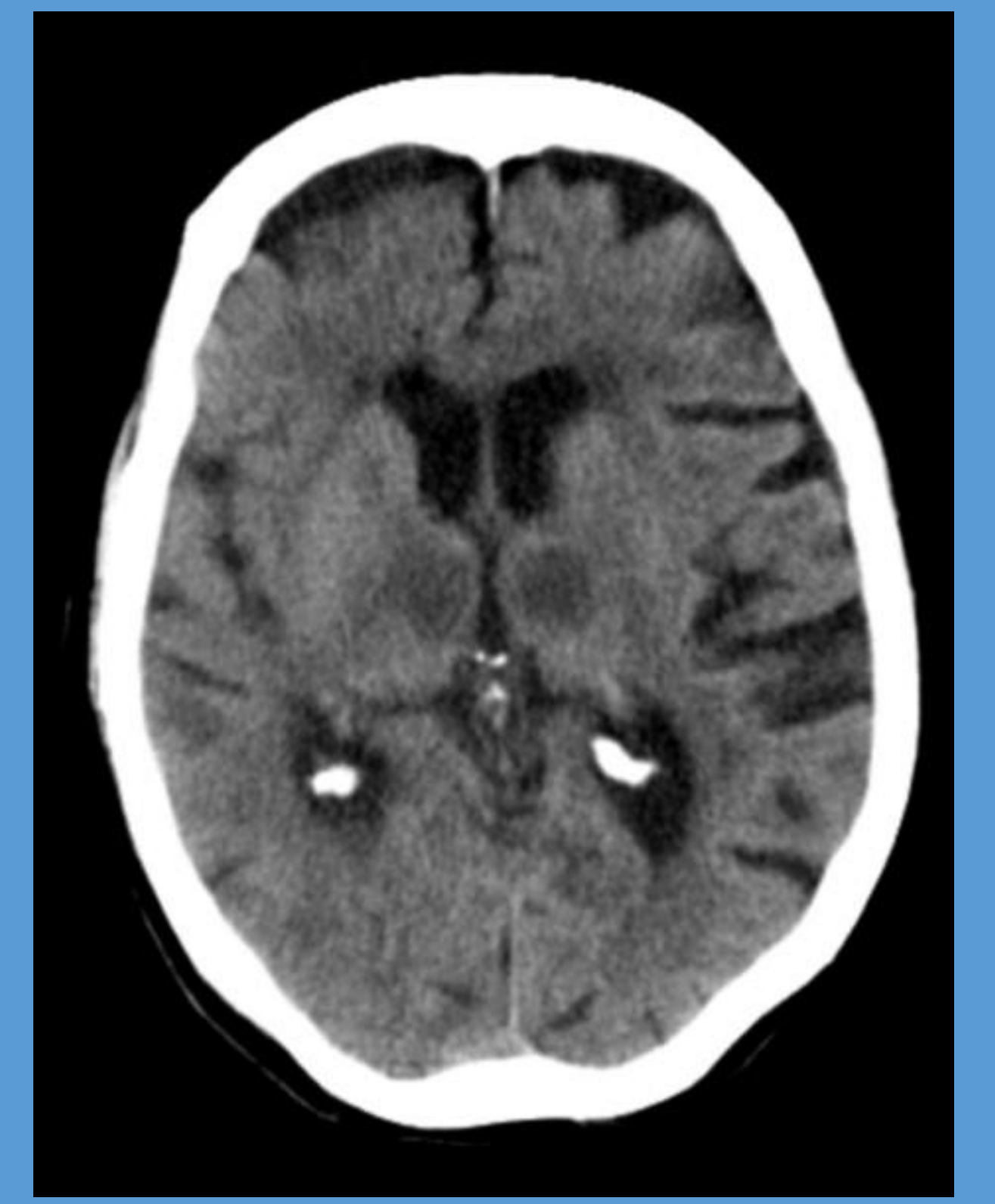

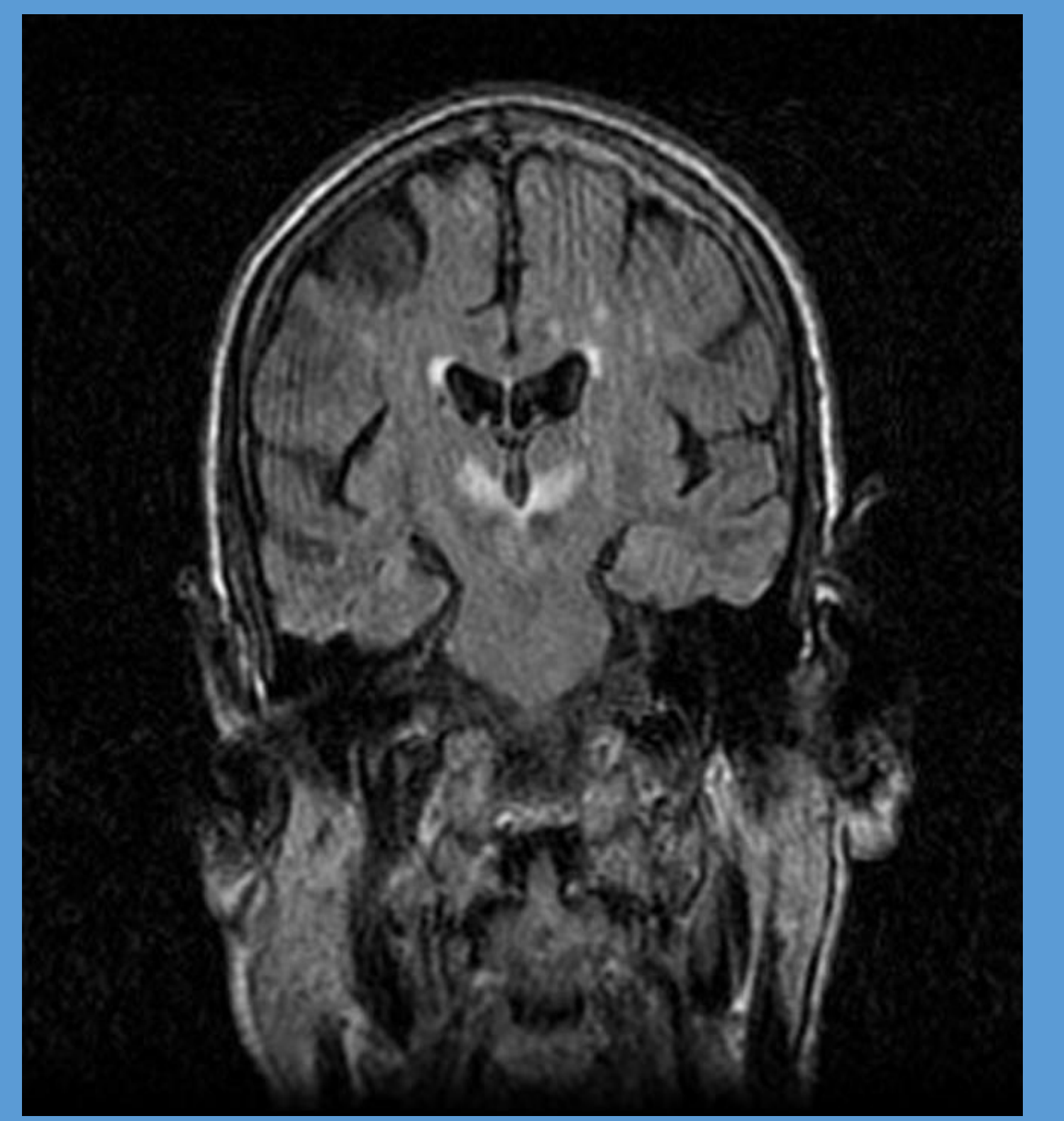

Discussion

Percheron artery syndrome requires a high degree of diagnostic suspicion, because it can very easily be confused with other pathologies that show an acute decrease in the level of consciousness, and which are managed differently. It is essential to pay attention to specific aspects of the physical examination, rather than to the neuroimaging tests available in hospital emergencies.

\title{
References
}

-De la Cruz-Cosme C, Márquez-Martínez M, Aguilar-Cuevas R, Romero-Acebal M, Valdivielso-Felices P. Síndrome de la arteria de Percheron: variabilidad clínica y diagnóstico diferencial. Rev Neurol 2011; 53: 193-200.

-Teoh H, Ahmad A, Yeo L, Hsu E, Chan B, Sharma V. Bilateral thalamic infarctions due to occlusion of artery of Percheron. J Neurol Sci 2010; 293: 110-1. -Lostra J, Tempra A, García-Saíz E, Valdivia-Rodríguez H. Momento anatómico: la arteria de Percheron. Importancia de su reconocimiento en resonancia magnética. Mar del Plata: Hospital Privado de Comunidad: 2010

-Raphaeli G, Liberman A, Gomori J, Steiner I. Acute bilateral paramedian thalamic infarcts after occlusion of the artery of Percheron. Neurology $2006 ; 66:$ e7. -Martí-Vilalta J.L Enfermedades vasculares cerebrales. $3^{a}$ ed. Barcelona: ediciones Mayo; 2012

Mohr J.P. Wolf P.A. Grotta J.C. Moscowitz M.A. Mayberg M. Von Kummer R. Stroke patophysiology, diagnosis and management. $5^{a}$ ed. Philadephia: Elsevier; 2011 